\title{
Production and photosynthetic activity of Mimosa Verde and Mimosa Roxa lettuce in two farming systems ${ }^{1}$
}

\author{
Aline Mabel Rosaㄹ, Hizumi Lua Sarti Seól, Maila Berté Volpatol, Nathalie Vieira Foz ${ }^{1}$, Tatiane Carine da Silval, \\ Jorge Luiz Barcelos Oliveira ${ }^{3}$, Rosete Pescador ${ }^{4}$, Juliana Bernardi Ogliari ${ }^{5}$ \\ http://dx.doi.org/10.1590/0034-737X201461040007
}

\begin{abstract}
Lettuce (Lactuca sativa L.) is the most commonly consumed leaf vegetable in the Brazilian diet, and it is a good source of vitamins and minerals. It is widely grown in the conventional farming system. However, the hydroponic farming system has been gaining importance in the market, wining confidence from consumers, who are becoming increasingly more demanding on food quality. The objective of this study was to evaluate the performance of two lettuce cultivars on hydroponic and conventional farming systems for the production of fresh mass (FM) and dry mass (DM), photosynthesis, contents of chlorophyll and anthocyanin. The following two experiments were carried out: hydroponics farming $(\mathrm{HF})$ and conventional farming $(\mathrm{CF})$, performed in protect and unprotect environments, respectively, in Florianópolis, SC. Mimosa Verde cultivar (MV) showed greater fresh mass than Mimosa Roxa (MR), in both farming systems and the two cultivars presented better performance in the hydroponic system (287.7 g MV and 139.1 g MR) than the conventional system (129.7 g MV and 111.8 g MR). Mimosa Verde cultivar presented lower average contents of total chlorophyll ( $\left.7.7 \mathrm{mg} \mathrm{g}^{-1} \mathrm{FM}\right)$ than Mimosa Roxa (11.8 $\left.\mathrm{mg} \mathrm{g}^{-1} \mathrm{FM}\right)$, and both cultivars displayed higher means for this variable in the hydroponic farming system. Mimosa Roxa presented higher contents of anthocyanin in the conventional system $\left(88.24 \mathrm{mg} \mathrm{g}^{-1} \mathrm{FM}\right)$ than the ones in the hydroponic system $\left(36.89 \mathrm{mg} \mathrm{g}^{-1} \mathrm{FM}\right)$. The best results for $\mathrm{CO}_{2}$ net assimilation rate regarded to photosyntheticaly active photon flux density were found in the hydroponic system, for both lettuce cultivars. Variation in the contents of chlorophyll were also found. Those variations were higher in the protected system than in the hydroponic system and contents of anthocyanin were higher in the conventional system.
\end{abstract}

Key words: biomass, Lactuca sativa, photosynthesis, anthocianin.

\section{RESUMO}

\section{Produção e atividade fotossintética de alface Mimosa Verde e Roxa em dois sistemas de cultivo}

A alface (Lactuca sativa L.) é a hortaliça folhosa mais consumida na alimentação do brasileiro, sendo boa fonte de vitaminas e de sais minerais. É largamente produzida no sistema convencional. No entanto, o cultivo hidropônico vem ganhando espaço no mercado, conquistando a confiança dos consumidores, cada vez mais exigentes com a qualidade dos alimentos. O objetivo deste trabalho foi avaliar o desempenho de duas cultivares de alface, nos sistemas de cultivo hidropônico e convencional, para a produção de massa fresca (MF) e massa seca (MS), fotossíntese, teores de

Received 18/09/2012; accepted 29/11/2013

${ }^{1}$ Practice study presented in Vegetable Growing (Agronomy) at Universidade Federal de Santa Catarina, coordinated by the last author.

${ }^{2}$ Agronomy undergraduate student. Universidade Federal de Santa Catarina, Rodovia Admar Gonzaga, 1346, Bairro Itacorubi, 88.040-900, Florianópolis, Santa Catarina, Brazil. linerosa@gmail.com

${ }^{3}$ Agronomist, Doctor of Science. Departamento de Engenharia Rural, Universidade Federal de Santa Catarina, Rodovia Admar Gonzaga, 1346, Bairro Itacorubi, 88040-900, Florianópolis, Santa Catarina, Brazil. jbarcelo@cca.ufsc.br

${ }^{4}$ Agronomist, Doctor of Science. Departamento de Fitotecnia, Universidade Federal de Santa Catarina, Rodovia Admar Gonzaga, 1346, Bairro Itacorubi, 88040-900, Florianópolis, Santa Catarina, Brazil. rosete.pescador@ufsc.br

${ }^{5}$ Agronomist, Doctor of Science. Departamento de Fitotecnia, Universidade Federal de Santa Catarina, Rodovia Admar Gonzaga, 1346, Bairro Itacorubi, 88040-900, Florianópolis, Santa Catarina, Brazil. juliana.bernardi@ufsc.br ou jbogliar@hotmail.com (corresponding author). 
antocianinas e de clorofilas. Foram conduzidos dois experimentos: um no sistema de cultivo hidropônico $(\mathrm{CH})$ e outro em cultivo convencional (no solo) (CC), realizados em ambientes protegido e desprotegido, respectivamente, no município de Florianópolis, SC. A cultivar Mimosa Verde (MV) apresentou maior peso de massa fresca, em comparação com Mimosa Roxa (MR), em ambos os sistemas de produção, e ambas as cultivares apresentaram melhor desempenho no sistema hidropônico (287,7 g MV e 139,1 g MR), em relação ao convencional (129,7 g MV e 111,8 g MR). A cultivar MV apresentou menores teores médios de clorofila total (7,7 $\left.\mathrm{mg} \mathrm{g}^{-1} \mathrm{MF}\right)$, quando comparada com MR (11,8 $\left.\mathrm{mg} \mathrm{g}^{-1} \mathrm{MF}\right)$ e ambas apresentaram teores médios mais elevados dessa variável no cultivo hidropônico. Para a cultivar MR, os teores de antocianinas, no cultivo convencional, foram superiores $\left(88,24 \mathrm{mg} \mathrm{g}^{-1} \mathrm{MF}\right)$ aos do cultivo hidropônico (36,89 $\mathrm{mg} \mathrm{g}{ }^{-1} \mathrm{MF}$ ). Os melhores resultados para a taxa de assimilação líquida de $\mathrm{CO}_{2}$, com relação à densidade de fluxo de fótons fotossinteticamente ativos, foram observados no cultivo hidropônico, para ambas as cultivares. Também se observou variação nos teores de clorofila, que foram maiores no ambiente protegido do sistema hidropônico, e antocianinas, que foram maiores no cultivo convencional.

Palavras-chave: antocianina, Lactuca sativa, fotossíntese, biomassa.

\section{INTRODUCTION}

The acknowledge of quality of life by the world population has increased the demand for healthy products (Neto et al., 2011). Lettuce (Lactuca sativa L.) is the leafy vegetable most consumed in the Brazilian diet because of its pleasant flavor, low price and for being a source of vitamins and minerals (Soares, 2002).

Lettuce is most grown in the conventional farming system, where this vegetable is grown directly in the soil, in a limited period of the year, with no restrictions on the use of chemical fertilizers and pesticides (Campos, 2005). However, demands by the consumers have increased, requiring the production of good quality lettuce all over the year. Therefore, the hydroponic farming, usually associated with the protected environment, have gained ground in the productive sector and conquered the preference of the consumer.

In addition to the reasons associated with the consumer profile, the hydroponic farming in protected environment is becoming more important due to the following factors: better use of the cultivation area, early harvest, more efficient nutrient use, better sanitary quality of the product and the possibility of controlling abiotic factors that restrict farming in certain seasons (Santos et al., 2008). Another positive aspect of such farming system is its potential contribution to the development of urban agriculture and household food production.

However, it is known that the photosynthetic process and the contraction of pigments in plants is directly affected by the quality of light, $\mathrm{CO}_{2}$ concentration, mineral nutrition and temperature (Taiz \& Zeiger, 2009). Thus, studies on farming systems and the understanding of the physiological and biochemical issues related to the quality and yield performance of crops are important aspects to consider for the adoption of the best suited farming system for each market segment.

The intake of chlorophyll as a component of the human diet contributes to tissue growth, acting as a substance promoting the multiplication of fibroblasts, which are connective tissue cells, responsible for the healing process (Tanaka, 1997). According to Hagiwara et al. (2001), anthocyanins have important biological activities for the human health, distinguishing themselves as being anticarcinogenic, antioxidant and antiviral. However, there are few studies relating the levels of anthocyanins and chlorophylls with morphophysiological performance of lettuce.

The objective of this study was to evaluate the performance of two lettuce cultivars in hydroponic and conventional farming systems for biomass production (dry mass and fresh mass), photosynthesis, contents of anthocyanins and chlorophylls.

\section{MATERIAL AND METHODS}

Two experiments were conducted to evaluate the performance of two lettuce cultivars (Mimosa Rosa Grenadine of Vilmorin ${ }^{\circledR}$; Mimosa Verde Salad Bowl, Sakata ${ }^{\circledR}$ ) in hydroponic (HF) and conventional (soil) (CF) farming systems, carried out in protected and unprotected environments, respectively, in Florianópolis, SC.

Regarding the conventional farming $(\mathrm{CF})$, an experimental area was used in conditions of open-field (unprotected) farming, located at the Centro de Treinamento (CETRE) of the Empresa de PesquisaAgropecuária e Extensão Rural de Santa Catarina-EPAGRI. It was used a complete random block experimental design with two treatments (lettuce cultivars) and four replications. The experimental plot consisted of four $2.4 \mathrm{~m}$ long rows, spaced 
by $0.40 \mathrm{~m}$ from each other. Each row consisted of seven plants, $0.40 \mathrm{~m}$ apart, setting a density of 6.25 plants $\mathrm{m}^{2}$. The useful area of the plot $\left(1.6 \mathrm{~m}^{2}\right)$ was formed by the two inner rows, excluding a plant from each end. Fertilization was performed according to the recommendation of the Manual of Fertilization and Liming for the states of Rio Grande do Sul and Santa Catarina for lettuce crop (CQFSRS/SC, 2004).

The hydroponic farming was carried out using the technique of the Laminar Flow of Nutrients (LFT) in the area assigned for the protected farming in the Hydroponics Laboratory (LabHibro) of the Agricultural Sciences Center (CCA) of UFSC, from September to October, 2011. The protected environment was provided by a bow-shaped greenhouse, with metal frame, with a ceiling height of 2.70 $\mathrm{m}$ and covered with transparent, diffusor type low density polyethylene film (LDPE), with 150 microns of thickness and UV treatment, with no gadgets to control humidity and temperature. It was used a completely randomized block experimental design with two treatments (lettuce cultivars) evaluated in experimental units with four plants and four replications. Plants were distributed in the final production bench, comprised of cultivation channels spaced by $0.25 \mathrm{~m}$ between each other and $0.25 \mathrm{~m}$ between holes. Planting density in this system was 16 plants $\mathrm{m}^{-2}$. The electrical conductivity of the cultivation solution was kept between 1.85 and $2.00 \mathrm{dS} / \mathrm{m}$ (deciSiemens per meter), being corrected every two days. The nutrient solution used was adapted from Furlani (1999), according to Barcelos-Oliveira (2008), comprised by the following nutrients: special Hydro ${ }^{\circledR}$ calcium nitrate $(750 \mathrm{ppm})$, potassium nitrate $(500 \mathrm{ppm})$, purified MAP (monoammonium phosphate) (150 ppm), magnesiumsulphate (400 ppm), copper sulphateat a concentration of $13 \%(0.15$ ppm), zinc sulfate at a concentration of $22 \%(0.50 \mathrm{ppm})$ manganese sulfate at a concentration of $26 \%(1.50 \mathrm{ppm})$, boric acid at a concentration of $17 \%$ (1.50 ppm), sodium molybdateat a concentration of $39 \%(0.15 \mathrm{ppm})$ and HydroFerro $^{\circledR}(30$ ppm).

Mimosa Roxa (MR) and Mimosa Verde (MV) cultivars commercial pelleted seeds with $100 \%$ purity and $96 \%$ germination were used in both trials. The seeds were germinated in phenolic foam and maintained in a hydroponics system for 29 days, until transplantation to their respective farming systems. During this period, the seedlings received the nutrient solution formulated by Furlani (1999) and the electrical conductivity of the solution was maintained between 0.90 and $1.40 \mathrm{dS} / \mathrm{m}$.

After lettuce growing period (63 days after sowing in the hydroponics system; 77 days after sowing in the conventional system), it was carried out the determination of total fresh mass (FM) and dry mass (DS), fresh root mass (FRM) and fresh leaf mass (FLM) and the number of leaves per plant (NL) was counted. For the determination of total fresh mass (FM) and dry mass (DM), a sample of two plants of the useful area of the plot of each treatment was harvested and weighed on a precision scale before and after drying. Drying was performed in an oven at $60^{\circ} \mathrm{C}$ for 72 hours, and weighing was made when the weight was constant. The percentage of DM was obtained by the relationship between the dry mass and fresh mass (Schena et al., 2007). The number of leaves per plant was counted manually in two plants sampled from each treatment.

Total concentration of chlorophyll was determined in healthy and complete leaves, obtained from eight plants sampled from the useful area of the plot of each cultivar, immediately after harvest. Samples of $100 \mathrm{mg}$ of fresh leaves were incubated in a water bath with $7 \mathrm{ml}$ of dimethylsulfoxide (DMSO) for two hours at $65^{\circ} \mathrm{C}$ and no maceration was done. After filtering, the total volume was adjusted to $10 \mathrm{ml}$. The values were obtained by spectrophotometry, considering the optical density measured at $645 \mathrm{~nm}$ and $663 \mathrm{~nm}$, according to the methodology described by Borghezan et al. (2003).

The content of anthocyanin was measured by the $\mathrm{pH}$ differential method, adapted from the method described by Giusti \& Wrolstad (2001). Thus, $100 \mathrm{~g}$ of sample were weighed to $50 \mathrm{~mL}$ of methanol extractor solvent acidified with $1 \% \mathrm{HCl}$ to obtain a higher concentration in the extract. The values of absorbance at wave lengths of 530 and 700 $\mathrm{nm}$ were obtained by spectrophotometry (Bel Photonics 2000 UV). The total contents of anthocyanin were expressed in milligrams of anthocyanins per 100 grams of fresh leaves ( $\left.\mathrm{mg} \mathrm{g}^{-1} \mathrm{FL}\right)$.

The curves of net $\mathrm{CO}_{2}$, assimilation rates in response to the photosynthetically active photon flux density (PPFD) of $0 ; 50 ; 100 ; 500 ; 1000 ; 1500$ and $2000 \mu \mathrm{mol} \mathrm{m}^{-2} \mathrm{~s}^{-1}$. were determined with the infrared gas analyzer (Licor Li 6400 XT Portable Photosynthesis System). The apparent quantum efficiency $\left(\mathrm{x}_{\mathrm{a}}\right.$; $\mu \mathrm{mol} \mathrm{CO}_{2} / \mu \mathrm{mol}$ photons $)$ was estimated by setting a linear equation in the range in which the variation of $A$ as a function of PPFD was linear, i.e., $A$ $=c+\left(\mathrm{x}_{\mathrm{a}} \times \mathrm{PPFD}\right)$, where $c$ and $\mathrm{x}_{\mathrm{a}}$ are adjustment parameters according to the methodology described by Mota et al. (2009). Evaluations were performed at the harvest point, on a fully expanded leaf, per plant, on the two central plants of each useful area of the plot, between 10 a.m. and 1 p.m. (Siebeneichler et al, 1998).

The results of production of fresh and dry mass of the plants (total fresh and dry mass and fresh mass of leaf and root) as well as the contents of chlorophyll and anthocyanins, were submitted to analysis of variance and Tukey's test ( $\mathrm{p}<0.05$ ) with the Statistica 6.0 (StatSoft, 2001) program. The results of photosynthetic assimilation were evaluated from the polynomial regression analysis. 


\section{RESULTS AND DISCUSSION}

The cultivation periods of lettuce in hydroponic (HF) and conventional (CF) farming systems were 63 and 77 days, respectively. The longest cultivation periods of the plants in the CF may be due to the development of new roots, replacing those existing in the plant at the time of transplantation, and are degraded after being transferred to the field, in contact with the soil (Beninni et al., 2005). This behavior does not occur in the HF, possibly because the water and all the nutrients are available in adequate amounts over the growing season. It is also important to consider that higher temperatures are generally reached in the protected cultivation, which tends to reduce the crop cycle.

The values of fresh weight (total, roots and leaves) were higher in the HF (Table 1). Differences for this trait among cultivars were found only in the HF. The MV cultivar presented, in the HF, statistically superior performance in all characteristics associated with fresh weight than the MR cultivar. The MV cultivar displayed a higher number of leaves in HF than MR cultivar. This performance differs from that obtained by Radin et al. (2004), who found a greater number of leaves on lettuce grown in a greenhouse and submitted to drip irrigation than those grown in soil at field conditions. According to these authors, the environment influences the development of plants and those grown in protected environments display a higher production of fresh mass of the leaf, but lower percentage of dry mass. The lower content of the dry mass of hydroponic lettuce is due to its greater hydration. Furthermore, the effect of the additional supply of nitrogen on production (Callegari et al., 2001) would also explain the variations between farming systems, regarding to the components of the biomass. This situation is an advantage to plants submitted to HF because the water and all the nutrients are in controlled amounts and proportions over the growing period, unlike the $\mathrm{CF}$, which is submitted to greater environmental changes.
Since this study was conducted during the rainy season, there may have been environmental variations in the conventional farming, which in turn may have affected the productive capacity of the two cultivars. Rainfall during the 77 farming days corresponded to $264.10 \mathrm{~mm}$, distributed in 23 days, equivalent to $29.8 \%$ of the expected rainfall in this period. The relative humidity reached a mean of $78 \% \pm 2.7 \%$ (September: $79.3 \%$; October: $80.1 \%$ and November: $75 \%$ ), while the average temperature was $19.4^{\circ} \mathrm{C}$ in $\mathrm{CF}$ and $24.7^{\circ} \mathrm{C}$ in $\mathrm{HF}$.

The total amount of chlorophyll varied significantly among cultivars and even more among the farming environments. The MR cultivar showed higher mean values of total chlorophyll than those achieved by MV cultivar in both farming environments (Figure 1). Paulus et al. (2010), who showed that the total amount of chlorophyll of the purple cultivar was 50\% higher than the green cultivar, obtained a similar result. Besides the genetic factors, these authors explain that these variations may also be due to the destruction of the structure of the chloroplast by the action of chlorophyllase, under conditions of salt stress. In this study, it is believed that the differences found in the content of chlorophyll between the two farming systems could be explained by the genetic constitution of the cultivars and by the less control of irrigation and fertilization in the field cultivation. However, it was not used any methodological procedures that would evidence these hypotheses in this study.

In both HF and protected environment, the plants showed higher amounts of total chlorophyll (Figure 1). This result can be explained by the control of the nutrients available in the $\mathrm{HF}$, especially nitrogen $(\mathrm{N})$ in the leaves, as a significant part of this macroelement takes part in the synthesis and structure of chlorophyll molecules (Taiz \& Zeiger, 2009). Similar results were found by Manzocco $e t$ al. (2011), who found a relationship between contents of chlorophyll and the highest concentration of nitrate in plants grown in the hydroponics system than in plants grown in the conventional farming system $(\mathrm{CF})$.

Table 1. Total fresh (FM) and dry mass (DM) accumulation, root fresh mass (RFM), leaf fresh mass (LFM), and number of leaves per plant (NL) at harvest, in two lettuce cultivars, Mimosa Verde (MV) and Mimosa Roxa (MR) in hydroponic (HF) and conventional farming systems $(\mathrm{CF})$

\begin{tabular}{|c|c|c|c|c|c|c|c|c|c|c|}
\hline \multirow{2}{*}{ Cultivar } & \multicolumn{2}{|c|}{ FM (g) } & \multicolumn{2}{|c|}{ DM (\%) } & \multicolumn{2}{|c|}{ RFM (g) } & \multicolumn{2}{|c|}{$\operatorname{LFM}(\mathbf{g})$} & \multicolumn{2}{|c|}{ NL } \\
\hline & $\mathbf{C F}^{\mathrm{NS}}$ & HF & $\mathbf{C F}^{\mathrm{NS}}$ & HF & $\mathbf{C F}^{\mathrm{NS}}$ & HF & $\mathrm{CF}$ & HF & CF & HF \\
\hline$\overline{\mathrm{MV}}$ & 129.68 & $287.69 \mathrm{a}$ & 14.06 & $11.91 \mathrm{a}$ & 11.71 & $38.34 \mathrm{a}$ & 13.61 & $33.50 \mathrm{a}$ & 38.63 & $27.31 \mathrm{a}$ \\
\hline MR & 111.79 & $139.07 \mathrm{~b}$ & 9.83 & $5.36 \mathrm{~b}$ & 8.60 & $19.60 \mathrm{~b}$ & 15.94 & $18.89 \mathrm{~b}$ & 32.00 & $17.81 \mathrm{~b}$ \\
\hline Mean & 120.74 & 213.38 & 11.95 & 8.63 & 10.16 & 28.97 & 14.77 & 26.20 & 35.31 & 22.56 \\
\hline $\mathrm{CV}(\%)$ & 30.91 & 5.26 & 7.11 & 6.77 & 30.43 & 11.23 & 34.47 & 12.49 & 8.20 & 10.73 \\
\hline$P$ value & 0.2695 & 0.0000 & 0.7620 & 0.0001 & 0.5066 & 0.0000 & 0.0249 & 0.0001 & 0.2531 & 0.0003 \\
\hline
\end{tabular}

Means followed by different letter in the same column differ from each other by the Tuckey's test at $5 \%$ of probability. ${ }^{\text {Ns }}$ Non-significant at $5 \%$ of probability by the $\mathrm{F}$ test. 
The contents of chlorophyll-a were more abundant than chlorophyll-b for the two cultivars and in both cultivation systems (Figure 1). This result is consistent with that described by Gross (1991), who confirms the higher abundance of chlorophyll-a, which corresponds to approximately $75 \%$ of green pigments found in plants.

In addition to supply controlling of water and nutrients, HF interferes in the solar radiation due to the covered environment provided by the protected farming. Galvani et al. (2001) emphasize that for the conditions of polyethylene covered greenhouse, the values of internal radiation during the day are smaller than the external ones because of the absorption and reflection of a fraction of direct radiation by polyethylene. As sunlight induces the synthesis of anthocyanins (Couto, 2009), this may explain the difference in the contents of this secondary metabolite among plants from the HF and CF (Figure 2). Moreover, according to Gobbo-Neto \& Lopes (2007), anthocyanin is an antioxidant flavonoid accumulated in superficial tissues, with protective action of chlorophyll against photo-destruction through the absorption of UVB rays. Therefore, lettuce grown in unprotected farming may present higher contents of anthocyanins in their leaves owed to the protective response against solar radiation.

The curves of net $\mathrm{CO}_{2}$ assimilation rates in response to photosynthetic photon flux density (PPFD) can be seen in Figure 3. For all treatments, as PPFD increases, the rate of $\mathrm{CO}_{2}$ assimilation increases up to a maximum point when photosynthesis tends to decrease from this value. The highest results for the net $\mathrm{CO}_{2}$ assimilation rates were found in MV and MR cultivars, in the HF system in which the maximum rate was achieved with photosynthetic photon flux density of 1758 and $1685 \mu \mathrm{mol} \mathrm{m} \mathrm{m}^{-2} \mathrm{~s}^{-1}$, respectively (Figure 3). Regarding MV and MR cultivars, the maximum photosynthetic activity was achieved with the photon flux density of 1740 and $1636 \mu \mathrm{mol} \mathrm{m} \mathrm{m}^{-2} \mathrm{~s}^{-1}$, respectively, in the CF system (Figure 3 ).

However, since photosynthetic efficiency is assessed per unit of area and the number of plants per unit of area may affect this variable, it should be considered the higher

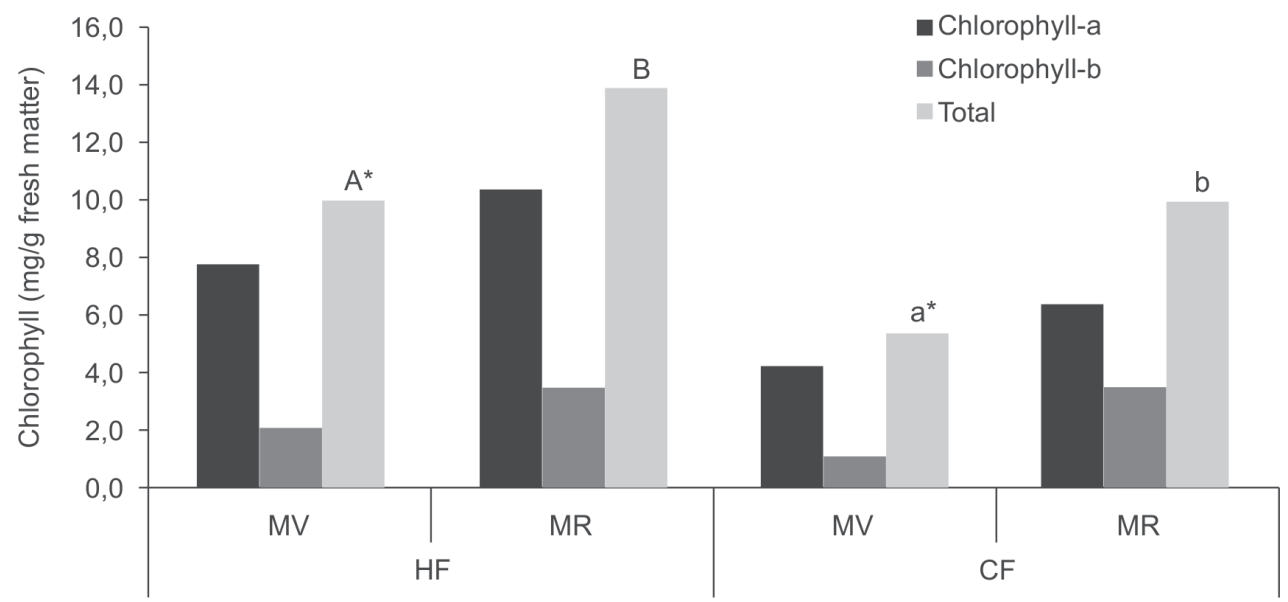

${ }^{(*}$ Means followed by the same letters, upper case letter for hydroponic farming system (HF) and lower case letter for conventional farming system (CF) do not differ from each other by the Tukey's test at $5 \%$ of probability. Values of $\mathrm{CV}(\%)=6,2$ for $\mathrm{CF}$ and $\mathrm{CV}(\%)=9,6$ for $\mathrm{HF}$.

Figure 1. Contents of chlorophyll-a and chlorophyll-b and total ( $\mathrm{mg} \mathrm{g}^{-1}$ of leaf fresh mass) and the relationship between chlorophylla and chlorophyll-b in two lettuce cultivars, Mimosa Verde (MV) and Mimosa Roxa (MR), in hydroponic (HF) and conventional farming system $(\mathrm{CF})$.

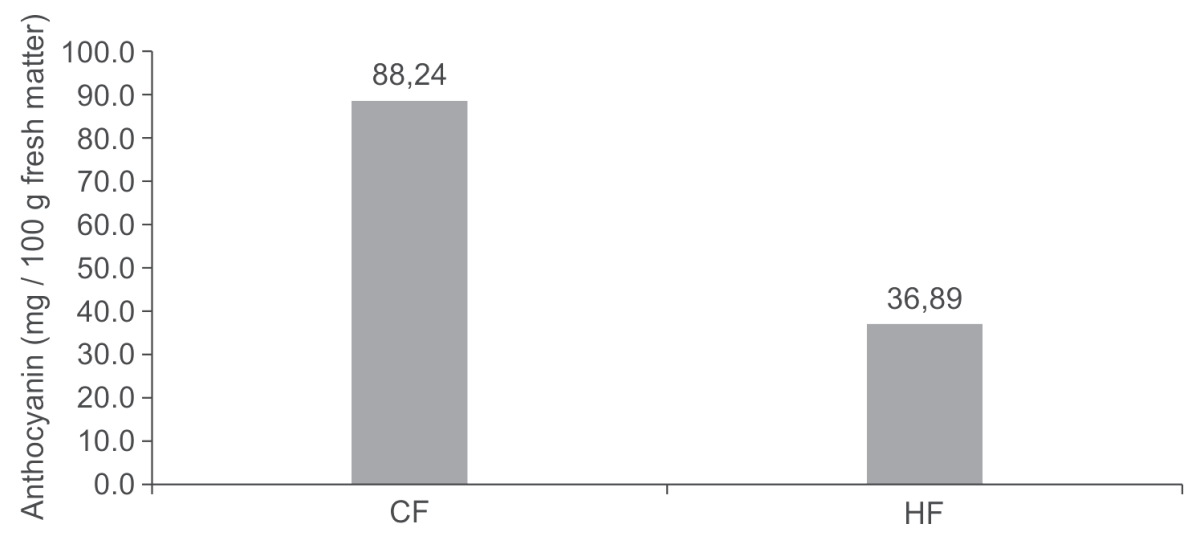

Figure 2.Contents of anthocyanin in $\mathrm{mg} 100 \mathrm{~g}^{-1}$ of lettuce (Mimosa Roxa cultivar) leaf fresh mass in hydroponic and conventional farming system.

Rev. Ceres, Viçosa, v. 61, n.4, p. 494-501, jul/ago, 2014 
plant density used in the $\mathrm{HF}\left(16\right.$ plants $\left.\mathrm{m}^{-2}\right)$ than in the $\mathrm{CF}$ (6.25 plants $\mathrm{m}^{-2}$ ). Thus, if the same analysis is made based on the individual plant, an increased photosynthetic efficiency is achieved in CF (mean of $241.1 \mu \mathrm{mol}$ PPFD plant $^{-1}$ ) compared to that achieved in HF (mean of 107.6 $\mu$ mol PPFD plant $\left.{ }^{-1}\right)$. For this reason, it is suggested that the intensity of light absorbed by the plant depends on the density of plants and on the environment where they are located.

The excess of light activates a mechanism that decreases its absorption to inhibit photosynthesis mainly by the photoinhibition process (Streit et al., 2005). The maximum rate of $\mathrm{CO}_{2}$ assimilation was achieved with PPFD

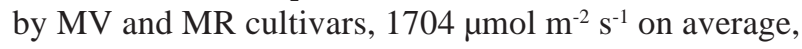
showing that the values higher than those may affect the process of photoinhibition in plants. Kim \& Hori (1989) comment that the photosynthetic rate correlates directly with the content of chlorophyll in the leaves. It was found in this study that regardless of the system used, MR cultivar showed a lower maximum $\mathrm{CO}_{2}$ assimilation rate in relation to PPFD compared with $\mathrm{MV}$, even with higher concentrations of chlorophyll contents. This decrease in photosynthetic activity by MR may be related to a typical response to radiation by the purple lettuce. This group of lettuce has a high metabolic cost of photoprotection, so that the plants divert the energy produced by photosynthesis to synthesize phenolic compounds, such as anthocyanins (Garcia-Macias et al., 2007; Tsormpatsidis et al., 2008; Tsormpatsidis et al., 2010).

The maximum $\mathrm{CO}_{2}$ assimilation rates were 15.53 and $14.18 \mu \mathrm{mol} \mathrm{m} \mathrm{m}^{-2} \mathrm{~s}^{-1}$ for MV and MR cultivars, respectively, grown in HF; these rates were 9.62 and $7.61 \mu \mathrm{mol} \mathrm{m} \mathrm{m}^{-2} \mathrm{~s}^{1}$ in MV and MR treatments in CF, respectively. The highest rates of photosynthetic activity found in HF can be explained by the features of the system, in which the availability of nutrient and water absorption are kept constant by the nutrient solution, favoring the stomatal opening and $\mathrm{CO}_{2}$ capture which increases efficiency of net $\mathrm{CO}_{2}$, assimilation as a consequence, as well as the higher average temperature, which has a positive effect on the net photosynthesis (Costa et al., 2001). On the other hand, these factors are poorly controlled in $\mathrm{CF}$, and they can be linked to issues related to soil, fertilizer and water and thermal fluctuations. Additionally, the lower energy deviation, derived from photosynthesis for photoprotection of greenhouse grown plants may also be an explanation for the higher maximum rates of $\mathrm{CO}_{2}$ assimilation obtained for the MV and MR cultivars, in the HF.

The higher photosynthetic rates found in hydroponic crops are evidenced by increase in the concentration of $\mathrm{CO}_{2}$ and temperature in greenhouses as well as the availability of water and mineral nutrients. Thus, the metabolism is stimulated and the rate of net $\mathrm{CO}_{2}$ assimilation is increased. Thus, the levels of $\mathrm{CO}_{2}$ rise because photorespiration decreases, as observed in the physiology of other C3-type species (Taiz \& Zeiger, 2009).

As the concentration of internal carbon increased, the rate of photosynthesis increased in all treatments. The highest values were found for MV and MR cultivars in the HF, in which the maximum net assimilation rates were 25 and $24.6 \mu \mathrm{mol} \mathrm{m} \mathrm{m}^{-2} \mathrm{~s}^{-1}$, respectively (Figure 4). MV and MR treatments achieved the values of 21.5 and $20.3 \mu \mathrm{mol}$ $\mathrm{m}^{-2} \mathrm{~s}^{-1}$ in CF. According to Zhou \& Han (2005), photosynthesis can be stimulated by the greater availability of $\mathrm{CO}_{2}$ and light. Thus, the increase in photosynthesis may be related to a greater availability of $\mathrm{CO}_{2}$ in the leaf. This can be confirmed by the increase in the concentration of internal carbon and by the consequent increase in the net assimilation rate.

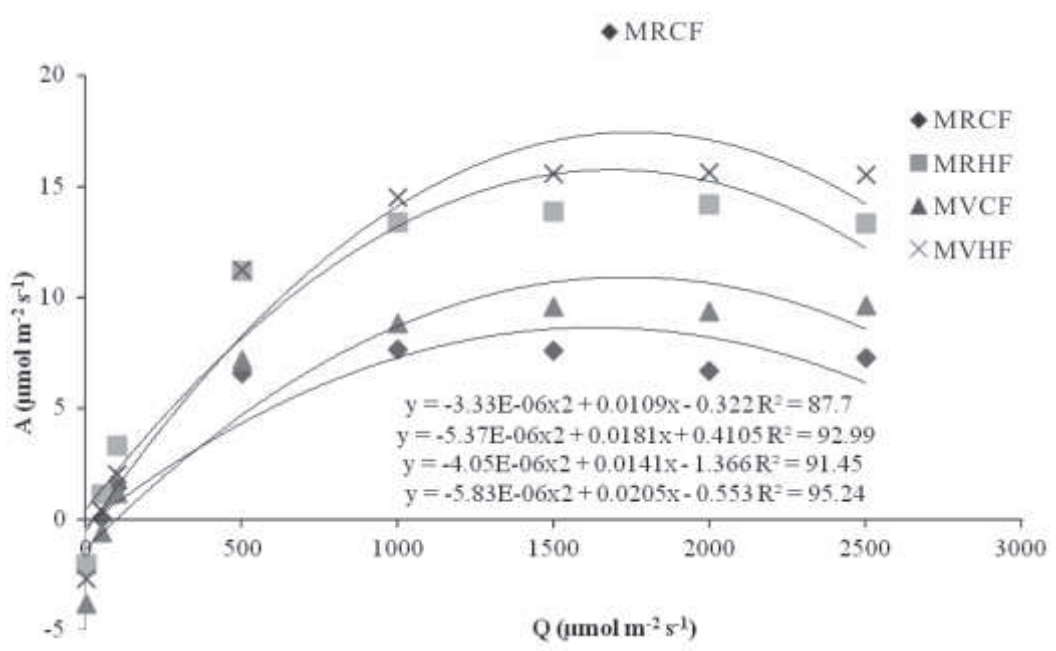

Figure 3. Net $\mathrm{CO}_{2}$ leaf assimilation rate (A) according to the photosynthetically photon flux density (Q), on two lettuce cultivars, Mimosa Verde, in conventional (MVCF) and hydroponic farming system (MVHF) and, Mimosa Roxa, in conventional (MRCF) and hydroponic farming system (MRHF). 


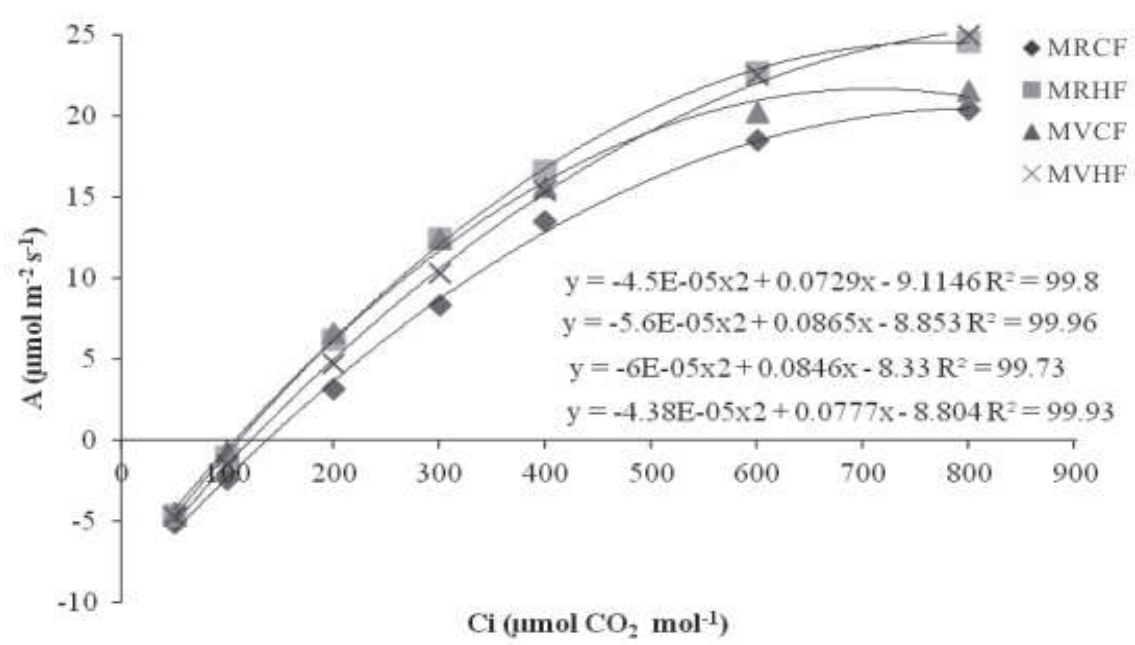

Figure 4. Net $\mathrm{CO}_{2}$ leaf assimilation rate (A) according to internal $\mathrm{CO}_{2}$ concentration (Ci), in two lettuce cultivars, Mimosa Verde, in conventional (MVCF) and hydroponic farming system (MVHF) and, Mimosa Roxa, in conventional (MRCF) and hydroponic farming system (MRHF).

The rate of photosynthesis, measured per unit of area $\left(\mathrm{m}^{2}\right)$ showed greater efficiency in $\mathrm{HF}$ than in the CF system. However, the specifications of the spacing between rows and among plants varied for each culture system. Based on the difference in planting density between the two systems, it may be seen that there were greater individual photosynthetic performances in the $\mathrm{CF}$ than in the $\mathrm{HF}$ in accordance with the results of the dry mass production, which was also higher in $\mathrm{CF}$ when the level of individual plant is compared. Similar results were obtained by Romano (2001).

In both systems evaluated, the increase of these components (chlorophyll and anthocyanins) can have a direct effect on the composition of the product and on the quality of the final product. Even though the relationship between quantity and quality of the consumed product is not much exploited in the context of agricultural studies, these data show the importance of understanding the physiological effects of the cultivation systems in order to manage the production according to the preferences of the consumer.

\section{CONCLUSIONS}

Protected environment associated with hydroponic farming system provided larger amounts of chlorophyll and higher rates of $\mathrm{CO}_{2}$ net assimilation for Mimosa Verde and Mimosa Roxa cultivars.

For Mimosa Roxa cultivar, conventional farming (plants grown in the soil in unprotected environment), provided greater amount of anthocyanins and a higher number of leaves per plant.

Despite the lower production of fresh and dry weight by Mimosa Roxa cultivar in both systems, a qualitative gain was found due to a higher content of anthocyanin, provided by conventional farming.

\section{REFERENCES}

Barcelos-Oliveira JL (2008) Formulação de correção para alface hidropônica em sistema NFT, com plantas de mesma idade na bancada final. In: II Encontro Sul-Brasileiro de Hidroponia, Florianópolis. Anais, Florianópolis, TecArt Editora. p.1825 .

Beninni ERY, Takahashi HW \& Neves CSVJ (2005) Concentração e acúmulo de macronutrientes em alface cultivada em sistemas hidropônico e convencional. Revista Semina, 26:273282 .

Borghezan M, Moraes LKA, Moreira FM \& Silva AL (2003) Propagação in vitro e avaliação de parâmetros morfofisiológicos de porta-enxertos de videira.Pesquisa Agropecuária Brasileira, 38:783-789.

Callegari O, Santos HS \&Scapim CA (2001) Variações do ambiente e de práticas culturais na formação de mudas e na produtividade da alface (Lactuca sativa L. cv. Elisa). Revista Acta Scientiarum, 23:1117-1122.

Campos MC (2005) Territorialização da agricultura orgânica no Paraná: preservando o meio ambiente e produzindo alimentos sadios. Disponível em: <http://www.igeo.uerj.br/VICBG-2004/ Eixo1/e1\%20279.htm> Acessado em: 13 de agosto de 2011.

Costa PC, Didone EB, Sesso TM, Cañizares KAL \& Goto R (2001) Condutividade elétrica de solução nutritiva de alface em hidroponia. Scientia Agrícola, 58:595-597.

Couto DLN (2009) Albedo em cerrado sensu stricto como resposta à variação climática e biológica - conexões com índice de vegetação, estoques de carbono e fluxos de CO2.Dissertação de Mestrado. São Paulo, Faculdade de Filosofia, Letras e Ciências Humanas, Universidade de São Paulo. 93p.

CQFS-RS/SC -Comissão de Química e Fertilidade do Solo - RS/SC (2004) Manual de adubação e calagem para os Estados do Rio Grande do Sul e Santa Catarina. 10 a ed. Porto Alegre, Sociedade Brasileira de Ciência do Solo - Núcleo Regional Sul. 394p.

Furlani PR, Silveira, LCP, Bolonhezi, D \&Faquim, V (1999) Cultivo hidropônico de plantas. Campinas, Instituto Agronômico. 52p. (Boletim Técnico 180).

Galvani E, Escobedo, JF \& Pereira AB (2001) Balanço de radiação e fluxo de calor no solo em ambiente natural e protegido cultivado com pepineiro. Bragantia, 60:139-147. 
Garcia-Macias P, Ordidge M, Vysini E, Waroonphan S, Battey NH, Gordon MH, Hadley P, Jones P, Lovegrive J \&Wagstaffe A (2007) Changes in the flavonoid and phenolic acid contents and antioxidant activity of red leaf lettuce (LolloRosso) due to cultivation under plastic films varying in ultraviolet transparency.Journal of Agricultural and Food Chemistry, 55:10168-10172.

Giusti, MM \&Wrolstad, RE (2001) Anthocyanins: characterization and measurement with uv-visible spectroscopy. Currentprotocols in foodanalyticalchemistry, 2:1-13.

Gobbo-Neto L \& Lopes NP (2007) Plantas medicinais: fatores de influência no conteúdo de metabólitos secundários. Química Nova, 30:374-381

Gross J. Pigments in vegetables, chlorophylls and carotenoids (1991). New York, Van Nostrand Reinhold. 351p.

Hagiwara A, Miyashita K, Nakanishi T, Sano M, Tamano S, Kadota T, Koda T, Nakamura M, Imaida K, Ito N \&Shirai T (2001) Pronounced inhibition by a natural anthocyanin, purple corn color, of 2-amino-16-phenylimidazol (4,5-b) pyridine (PhIP)associated colorectal carcinogenesis in male F344 rats pretreated with 1,2-dimethylhydrazine. Cancer Letters, 171:17-25.

Kim JH \& Hori Y (1989) Studies on growth andphotosynthetic capacity of aubergine (Solanummelongena) leaves. Journal of the JapaneseSociety for Horticultural Science, 54:371-378.

Manzocco L, Foschia M, Tomasi N, Maifreni N, Dalla Costa L, Marino M, Cortella G \&Gesco S (2011) Influence of hydroponic and soil cultivation on quality and shelf life of ready-to-eat lamb's lettuce (Valerianellalocusta L. Latter). Journal Science FoodAgriculture, 91:1373-1380.

Mota CS, Amarante CVT, Santos HP \& Albuquerque JA (2009) Disponibilidade hídrica, radiação solar e fotossíntese em videiras 'Cabernet Sauvignon' sob cultivo protegido. Revista Brasileira Fruticultura, 31:432-439.

Neto FB, Goes SB, Sá JR, Linhares PCF, Goes GB, G.B \& Moreira JN (2011) Desempenho agronômico da alface em diferentes quantidades e tempos de decomposição de jitirana verde. Revista Brasileira Ciências Agrárias, 6:236-242.

Paulus D, Dourado-Neto D, Frizone JA \& Soares TM (2010) Produção e indicadores fisiológicos de alface sob hidroponia com água salina. Horticultura Brasileira, 28:29-35.

Radin B, Reisser Júnior C, Matzenauer R \&Bergamaschi H (2004) Crescimento de cultivares de alface conduzidas em estufa e a campo. Horticultura Brasileira, 22:178-181.
Romano MR (2011) Análise de crescimento, produção de biomassa, fotossíntese e biossíntese de aminoácidos em plantas transgênicas de tabaco (Nicotianatabacum L.) que expressam o gene Lhcb1*2 de ervilha. Dissertação de Mestrado. Piracicaba, Escola Superior de Agricultura "Luiz de Queiroz". 66p.

Santos AO, Neto BLR, Zwirtes DS, Silva RB \&Yonenaga WH (2008) Produção de alface hidropônica: uma abordagem pela dinâmica de sistemas. In: $4^{\circ}$ Congresso Brasileiro de Sistemas, Franca. Anais, Centro Universitário de Franca Uni-FACEF.

Siebeneichler SC, Sant'Anna R, Martinez CA, Mosquim PR \& Cambraia J (1988) Alteração na Fotossíntese, Condutancia Estomática e Eficiência fotoquímica induzidas por baixa temperatura e, Feijoeiro. Revista Brasileira de Fisiologia Vegetal, $10 ;$ p. $37-44$

Schena TE, Garbuio PW, Weirich Neto PH \& Souza NM (2007) Determinação da matéria seca de plantas de milho (ZeamaysL.) destinadas à produção de silagem.In: $3^{\circ}$ Encontro de Engenharia e Tecnologia de Campos Gerais, Ponta Grossa. Universidade Estadual de Ponta Grossa (UFPG). p.1-7.

Soares I (2002) Alface: cultivo hidropônico. Fortaleza, Editora UFC. $50 \mathrm{p}$

StatSoft (2001). Statistica 6.0. Tulsa, Oklahoma, USA.CD-ROM.

Streit, NM, Canterle LP, Canto MW \&Hecktheuer LH (2005) As clorofilas. Ciência Rural, 35: 748-755.

Taiz L \&Zeiger E (2009) Fisiologia Vegetal. 4ª ed. Porto Alegre, Artmed. 474p.

Tanaka K, Yamada A, Noda K, Shoyama Y, Kubo C \& Nomoto K (1997) Oral administration of an unicellular green algae, Chlorella vulgaris, prevents stress-induced ulcer. Planta Medica, 63:465-466.

Tsormpatsidis E, Henbest RGC, Davis FJ, Battey NH, Hadley P \&Wagstaffe A (2008) UV irradiance as a major inûuence on growth, development and secondary products of commercial importance in LolloRosso lettuce 'Revolution' grown under polyethylene ûlms. Environmental and Experimental Botany, $63: 232-239$.

Tsormpatsidis E, Henbest RGC, BatteyNH, Hadley P (2010) The influence of ultraviolet radiation on growth, photosynthesis and phenolic levels of green and red lettuce: potential for exploiting effects of ultraviolet radiation in a production system. Annals of Applied Biology, 156:357-366.

Zhou YM \& Han SJ (2005) Photosynthetic response and stomatal behaviour of Pinuskoraiensis during the fourth year of exposure to elevated $\mathrm{CO}_{2}$ concentration. Photosynthetica, 43:445-449. 